\title{
Ability of invasive green crabs to handle prey in a recently colonized region
}

\author{
Gesa Schaefer ${ }^{1,2}$, Martin Zimmer ${ }^{1,3,4, *}$ \\ ${ }^{1}$ Zoologisches Institut, Christian-Albrechts-Universität zu Kiel, 24118 Kiel, Germany \\ ${ }^{2}$ Bamfield Marine Sciences Centre, 100 Pachena Road, Bamfield, British Columbia V0R 1B0, Canada \\ ${ }^{3}$ FB3: Benthic Ecology, IFM-GEOMAR, Leibniz-Institut für Meereswissenschaften, 24105 Kiel, Germany \\ ${ }^{4}$ Present address: FB Organismische Biologie, AG Ökologie, Biodiversität \& Evolution der Tiere, Paris-Lodron- \\ Universität Salzburg, 5020 Salzburg, Austria
}

\begin{abstract}
During the past few decades, the green crab Carcinus maenas, a native to Europe, has invaded the North American Pacific coast. In this new habitat, $C$. maenas encounters North American periwinkles of the genus Littorina that differ from European Littorina spp. in size, shape and shell strength. We hypothesize that the ability to handle prey never encountered previously is a prerequisite for successful invasion of novel habitats. In a first approach to testing our hypothesis, we compared European (native) to Canadian (invaded) C. maenas in feeding trials with Littorina spp. from Europe as well as Canada. Canadian crabs had significantly larger crusher claws than European crabs of the same size. Prey handling by Baltic crabs, but not by North Sea crabs, significantly depended on shell morphometry and strength of European periwinkles. By contrast, neither European nor Canadian crabs were affected by shell characteristics of the relatively softshelled Canadian periwinkles. Baltic and Canadian crabs did not differ in terms of handling time for, and handling success of, different periwinkle species, but North Sea crabs needed more time for, and were less successful in, crushing periwinkles. We conclude that $C$. maenas exhibits plasticity in both claw morphometry and feeding behaviour that enables this predator to handle novel prey organisms, and contributes to its success as an invader.
\end{abstract}

KEY WORDS: Predator-prey interaction - Invasive species · Carcinus maenas $\cdot$ Littorina spp Prey morphometry $\cdot$ Predator morphometry

Resale or republication not permitted without written consent of the publisher

\section{INTRODUCTION}

For understanding invasion processes, it is essential to gain insight into the basic mechanisms of invasion success that underlie biotic interactions of invaders in their novel habitat (cf. Lockwood et al. 2007). To this end, being released from enemies that exert pressure on a species in its native range may facilitate its establishment in a novel habitat ('enemy release': Elton 1958). On the other hand, every establishing individual will have to face thus far unknown competitors, and predators will have to acclimate to novel prey with unknown characteristics and defense mechanisms.
Predation is an important evolutionary and ecological factor that affects the composition and structure of communities, the demographic characteristics of populations, and the activity and life style of individuals (Lima \& Dill 1990). Upon establishment of an invader in a novel habitat, some species will change phenotypically more readily than others because of differences in the strength and persistence of newly developed interactions (Edgell \& Rochette 2008). For instance, Smith \& Palmer (1994) demonstrated plasticity in morphology and claw strength of predaceous crabs: crabs eating mussels without shells grew smaller and weaker claws than crabs eating intact mussels with shells. Similarly, crusher-claw size of 
invasive crabs increased significantly (relative to carapace width) for crabs raised on thick-shelled rather than thin-shelled diet (Baldridge \& Smith 2008), and the treatment of snail prey by crabs, i.e. shell-breaking versus flesh-winkling, depended on snail shell thickness (Edgell \& Rochette 2009). Conversely, mussels and snails can respond with plastic traits that confer resistance to predators, such as increasing shell thickness in response to water-borne cues from shell-crushing predators or damaged prey (Dalziel \& Boulding 2005). Differential predation pressure and/or different pre-invasion histories of prey species (cf. Vermeij 1982) result in speciesspecific responses to neobiotic predators (Edgell \& Rochette 2008). Morphological plasticity of prey organisms in response to predation pressure has recently become a focal issue in ecological studies on trophic interactions (for review, see Kishida et al. 2010), but rarely has predator plasticity been taken into account (cf. Edgell \& Rochette 2009).

The European green crab Carcinus maenas, the most common crab species in the North Sea and the Baltic Sea, is a strong competitor and a dominant benthic predator. Its native range stretches from Mauritania in north-western Africa through Atlantic Europe to northern Norway and Iceland (Behrens Yamada \& Gillespie 2008). Carcinus maenas successfully invaded both the Atlantic coast and, more recently, the Pacific coast of North America (Cohen et al. 1995, Breen \& Metaxas 2003) and other coasts throughout the world (cf. Behrens Yamada et al. 2010). Populations on North American Pacific coasts probably derived secondarily from earlier multiple invasions of the North American Atlantic coast during the 19th century (Darling et al. 2008). Following the strong El Niño event of 1997-1998, coastal currents transported crab larvae from source populations in California northwards to the Pacific Northwest coast of North America, where local recruitment ensured the establishment of stable populations (Behrens Yamada \& Gillespie 2008). Only in some places along the North American Pacific coast where the native Red rock crab Cancer productus acts as predator on $C$. maenas could the invasive crab not become established (Hunt \& Behrens Yamada 2003). Its success as a global invader is based on its tolerance to a wide range of temperature and salinity as well as its ability to thrive on a diversity of prey organisms (Cohen et al. 1995, Behrens Yamada et al. 2010). Hard-shelled prey organisms, such as mussels (e.g. Mytilus edulis) and snails (e.g. Littorina spp.) may strongly affect the crab's invasion success in a particular habitat, because shape and strength of their shells may pose an obstacle to their predators' predation success. However, phenotypic plasticity in feeding structures may allow invasive predators, such as C. maenas (Baldridge \& Smith 2008), to adjust to variation in prey defenses.

Periwinkles of the genus Littorina are commonly found in intertidal and subtidal habitats around the world (Reid 1996). Primarily grazing on microalgae and macroalgae, periwinkles may influence algal distribution in areas where they are abundant. Some species of Littorina (e.g. the Palearctic L. littorea and the Northern Pacific L. scutulata) have long-lived pelagic larvae and sites of distinct habitats are thus recruited from a common gene pool. This largely prevents local adaptation, but minor adjustments to the conditions of their prospective habitats are possible through individual phenotypic plasticity. Other species of the genus (e.g. the Palearctic L. fabalis and the Northern Pacific L. sitkana) develop directly without larval dispersal, and among these there is evidence for strong local adaptation forming distinct ecotypes in contrasting habitats (Behrens Yamada et al. 1998, Johannesson 2003). Differences in shell shape or strength among contrasting habitats have often been explained as adaptive to predators or wave action (Reid 1996, Edgell \& Rochette 2008).

On the other hand, crabs should preferentially prey upon those species and individuals that provide the best benefit:cost ratio (cf. Enderlein et al. 2003). For C. maenas in their northern native range, this seem to be medium-sized Littorina littorea and L. fabalis, the most common periwinkle species in the Baltic and North Sea, and Mytilus edulis, regardless of their hard shell. On the invaded northern Pacific coasts, 4 periwinkle species are common, namely $L$. scutulata, L. sitkana, L. subrotundata and L. plena (Boulding \& Harper 1998), in addition to a number of clams and mussels (cf. Behrens Yamada \& Boulding 1998). Invasive green crabs compete for these potential prey items with at least 3 native Pacific crab species, namely Cancer productus, Cancer magister and Hemigrapsus nudus (Rochette \& Dill 2000, Keppel \& Scrosati 2004, but see Lewis et al. 2007). Adaptation and/or acclimation with respect to morphometry and behavior that renders an invasive predator able to handle novel prey is a prerequisite to success in the invaded habitat.

Considering the recent success of Carcinus maenas in establishing stable populations along the North American Pacific coast (Behrens Yamada \& Gillespie 2008), we hypothesized that (1) geographically distinct populations of C. maenas in native and invaded habitats differ in claw morphometry in response to 
conditions in the biotic environment, and (2) C. maenas is able to successfully handle previously unknown prey. Hence, we predicted that Baltic and North Sea green crabs would be no better at handling European snails than snails from the Pacific, and green crabs from the Pacific would not be more successful in preying on Pacific snails than Baltic or North Sea crabs.

\section{MATERIALS AND METHODS}

The experiments were implemented between May and October 2009 with male European green crabs from the Baltic Sea and the North Sea at the University of Kiel (Zoological Institute), Germany, and with male Canadian green crabs from the Northeast Pacific at the Bamfield Marine Sciences Centre, Vancouver Island, British Columbia, Canada. Only healthy and intact crabs were used.

\section{Crabs}

Baltic crabs were caught with a trap in the inner Kiel fjord (54 $19^{\prime} 49^{\prime \prime} \mathrm{N}, 10^{\circ} 8^{\prime} 60^{\prime \prime} \mathrm{W}$ ) and by dredging in the outer Kiel fjord (54 $\left.23^{\prime} 44^{\prime \prime} \mathrm{N}, 10^{\circ} 11^{\prime} 28^{\prime \prime} \mathrm{W}\right)$. North Sea crabs were caught using filter traps on the North Sea island Helgoland (54 $10^{\prime} 60^{\prime \prime} \mathrm{N}, 7^{\circ} 53^{\prime}$ $\left.23^{\prime \prime} \mathrm{W}\right)$ and by hand on the shore of Föhr Island (54 $\left.{ }^{\circ} 41^{\prime} 29^{\prime \prime} \mathrm{N}, 8^{\circ} 34^{\prime} 24^{\prime \prime} \mathrm{W}\right)$. Crab size varied from 40 to $60 \mathrm{~mm}$ carapace width. Canadian crabs were caught with a bait-loaded trap in Pipestem Inlet $\left(49^{\circ} 2^{\prime} 41^{\prime \prime} \mathrm{N}, 125^{\circ} 12^{\prime} 6^{\prime \prime} \mathrm{W}\right)$ and close to Hiller Island $\left(49^{\circ} 1^{\prime} 51^{\prime \prime} \mathrm{N}, 125^{\circ} 18^{\prime} 20^{\prime \prime} \mathrm{W}\right)$. Those crabs were on average bigger than European crabs (60 to $80 \mathrm{~mm}$ carapace width). For this reason, all data obtained from feeding trials were standardized by the numeric relation of crab size:snail size (see below).

In the lab, each crab was kept separately in plastic aquaria. The aquaria $(25 \times 15 \times 15 \mathrm{~cm})$ in Germany were connected via a circulation system. Water was replaced weekly by filtered seawater from the Kiel

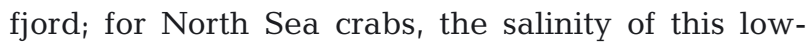
salinity Baltic water was raised artificially to an appropriate level. A flow-through system was built for the green crabs collected in Canada. Fresh seawater from the Bamfield inlet ran continuously through the aquaria $(34 \times 20 \times 18 \mathrm{~cm})$.

All crabs were fed with crushed periwinkles twice a week. Light/dark cycles were fitted to the natural day and night conditions in the current season. The experiments were run in the phase of darkness to take into account the crabs' diurnal activity (Naylor 1960, Crothers 1968). Water temperature in the aquaria was maintained at about $12^{\circ} \mathrm{C}$.

Carapace width and propodus height of each individual crab were measured with a digital caliper (accuracy $0.05 \mathrm{~mm}$ ). According to the strong correlation between both parameters (see 'Results'), we used propodal height both as measure for crab size and for standardization of experimental data to crab size.

\section{Periwinkles}

Four species of periwinkles were used as prey for the green crabs. Baltic Littorina littorea periwinkles were collected via dredging in the outer Kiel fjord $\left(54^{\circ} 23^{\prime} 44^{\prime \prime} \mathrm{N}, 10^{\circ} 11^{\prime} 28^{\prime \prime} \mathrm{W}\right)$. North Sea L. littorea periwinkles were hand-picked from the shore of Föhr

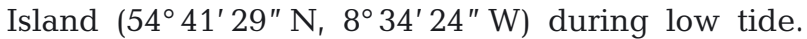
Littorina fabalis were provided by the Institute for Marine Ecology in Tjärnö, Sweden (58 $14^{\prime} 42^{\prime \prime} \mathrm{N}$, $11^{\circ} 27^{\prime} 33^{\prime \prime}$ W). Littorina scutulata and L. sitkana were picked by hand on shores around Bamfield $\left(48^{\circ}\right.$ $\left.50^{\prime} 6^{\prime \prime} \mathrm{N}, 125^{\circ} 8^{\prime} 8^{\prime \prime} \mathrm{W}\right)$.

European periwinkles were assigned to 3 size classes, small (5-6 $\mathrm{mm}$ shell height), medium (7-8 mm shell height), and large (10-11 $\mathrm{mm}$ shell height). Canadian crabs were fed larger periwinkles (small: 9-10 mm shell height, medium: 10-11 mm shell height, and large 11-12 mm shell height) which compensated for the larger sizes of Pacific crabs. Only live animals with intact shells were used in the experiments. The periwinkles were kept in separate aquaria separated by species.

Salinity of seawater from the Kiel fjord was raised artificially for periwinkles from the North Sea, Sweden and Canada. Water temperature was maintained at $12^{\circ} \mathrm{C}$. Fresh algae were available to the periwinkles ad libitum as food source; algal thalli were replaced about 3 times a week, depending on their condition.

For numerical description of interspecific differences in shell shape (Fig. 1), we measured 10 individuals of each size class of each species for shell height $(\mathrm{SH})$, shell width (SW), aperture height $(\mathrm{AH})$ and aperture width (AW) (see Fig. 1) with a digital caliper (accuracy $0.05 \mathrm{~mm}$ ). For morphometric comparison, we calculated ratios of these parameters that described various length:width relations of the shells. Statistically significant differences between Littorina species were detected through an all-pairwise multiple comparison procedure (Bonferroni $t$-test). 

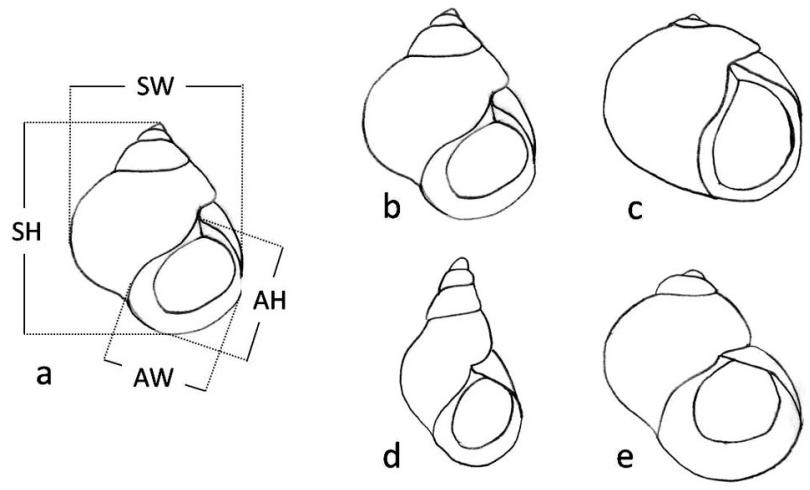

Fig. 1. Litterina spp. (a) Measures of periwinkle shell morphometry, and interspecific differences in shell shape between L. littorea (b) and L. fabalis (c) from Northern Europe, and L. scutulata (d) and L. sitkana (e) from the Canadian Pacific coast

Shell strength of the different Littorina species was measured with a texture analyzer (TA.XT2i 'Stable Micro Systems', pressure sensor Ø $2 \mathrm{~mm}, 3.142 \mathrm{~mm}^{2}$ ) with 10 individuals of each size class of each species. All tested periwinkles were positioned in a stable position with the aperture facing down to the pad below them and the pressure sensor centered above the highest point of the shell.

Both morphometric ratios and shell strength served as independent factors in multiple regression analyses to elucidate which shell characteristics of the prey influence the time a crab needs to handle a given snail as prey ('handling time', i.e. from first contact to access to snail flesh). Ratios that did not show a statistically significant difference among Littorina species were not included in the analysis.
A single periwinkle was carefully placed in the center of the crab aquarium. Handling time was defined as time from the crab picking up the periwinkle to the point at which it started to consume the snail flesh. Crabs that did not show any response to the offered prey were excluded from the analysis. When the crab was not successful within $30 \mathrm{~min}$, the experiment was terminated. Handling times were standardized for the ratio of the crab's propodal height to the snail's shell height.

Feeding trials also provided information on handling success. Crabs which were not able to crush a periwinkle (within $30 \mathrm{~min}$ ) were indicated as unsuccessful. As for the other experimental data, an allpairwise multiple comparison procedure (Bonferroni $t$-test) was used for the statistical analysis of handling time. The significance of the handling success experiments was tested with a $\chi^{2}$-test.

\section{RESULTS}

\section{Crabs}

On average, Carcinus maenas from Europe and Canada differed in carapace width, the latter being ca. 1.5 times larger, but all populations showed a significant correlation between carapace width and claw size, explaining $45 \%$ to $76 \%$ of within-population variation in claw size (Fig. 2). Claws were larger (relative to carapace width) in Canadian than in European (especially North Sea) crabs, but claw size increment with increasing carapace width did not differ among populations.

\section{Predator-prey interactions}

For feeding experiments, we used 20 to 30 crabs from each geographic region in this study, depending on their availability. Crabs were maintained individually in aquaria throughout the experiment in order to avoid disturbances and were observed one at a time. Each crab was offered periwinkles of each size class and species, except for Pacific crabs that could only be tested with Pacific periwinkles. Each crab was offered only one individual Littorina at a time in a randomized sequence. To prevent feeding saturation and ensure crabs remained hungry, a minimum time interval of $24 \mathrm{~h}$ was used between feeding assays.

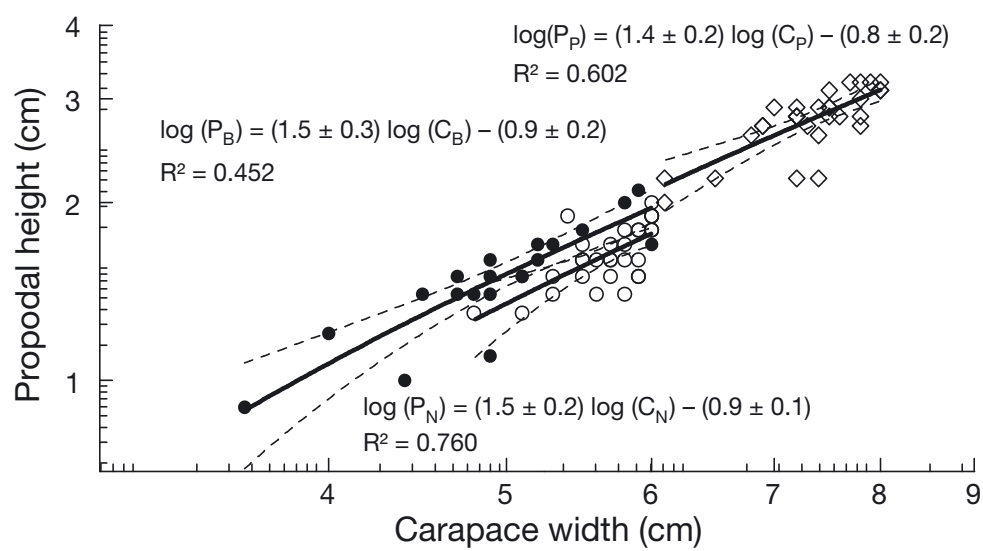

Fig. 2. Carinus maenas. Body (carapace width: C) and claw (propodal height: P) size of crabs from their native ranges in the Baltic (Bi filled circles) and North Sea ( $\mathrm{N}$ i open circles), and from an invaded region in the Pacific (p; diamonds) 


\section{Periwinkles}

Periwinkles from Europe and Canada exhibited interspecific differences in their morphometry. Of several parameter combinations, shell height:shell width (SH:SW), shell height:aperture height (SH:AH) and shell height:aperture width (SH:AW) proved valuable for shell shape discrimination because of significant differences in these ratios among species (not shown). Littorina fabalis had a clearly more globose shell shape, with small SH:SW and $\mathrm{SH}: \mathrm{AH}$ ratios that, in turn, were highest for L. scutulata with its high-spired and slender shape. Similar, SH:AW ratios were lowest in L. fabalis and highest in L. SCutulata, suggesting a larger aperture opening in the former than in the latter. Aperture width was also larger in L. sitkana than in L. littorea; otherwise these species were similar in shape (cf. Fig. 1). Shell morphometry only slightly changed from small to medium-sized to large individuals (not shown).

By contrast, interspecific differences in sizecorrected shell strength arose with increasing periwinkle size. To this end, small and medium-sized periwinkles exhibited essentially no interspecific differences in shell strength, but large individuals did (Fig. 3). Pacific periwinkles had weaker shells than European periwinkles, with $L$. littorea from the Baltic exhibiting the strongest shells.

\section{Predator-prey interactions}

For Baltic crabs, periwinkle shell shape proved significant for handling time (i.e. how long it took a crab to grab and open the shell). Of the shell ratios measured, SH:SW ( $p=0.037), \mathrm{SH}: \mathrm{AH}(\mathrm{p}=0.05), \mathrm{AH}: \mathrm{AW}$ $(p=0.001)$ and AW:SW ( $p=0.047)$, as well as shell strength $(p<0.001)$, significantly correlated (multiple regression) with handling time. In contrast, crabs from the North Sea and the Pacific were not affected in their handling of periwinkles by any of these parameters, the former hardly being successful at all (see below).

Small and medium-sized periwinkles of all species and locations did not differ in how long it took crabs from any location to handle them (data not shown). By contrast, large individuals of Littorina sitkana, $L$. scutulata and L. littorea from the North Sea were crushed significantly faster by Baltic crabs than hardshelled L. fabalis or L. littorea from the Baltic (Fig. 4).

Baltic crabs were significantly faster in handling North Sea Littorina littorea than were North Sea crabs, but generally these European populations dif-

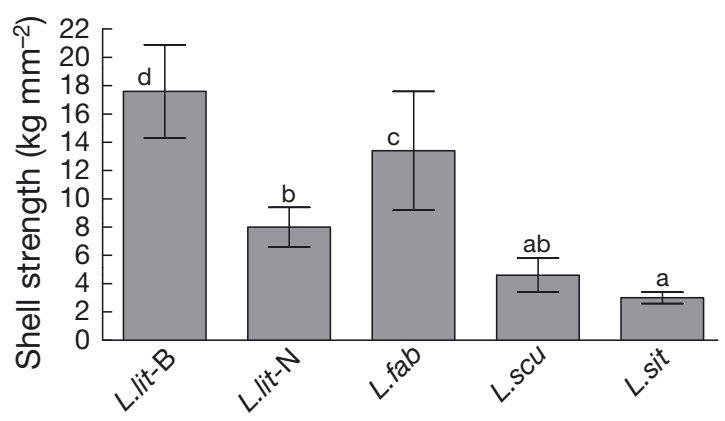

Fig. 3. Littorina sp. Interspecific differences in shell strength of large periwinkles. L.lit $=L$. littorea; L.fab $=L$. fabalis $($ North Sea $) ;$ L.SCu $=$ L. scutulata $($ Pacific $) ;$ L.sit $=$ L. sitkana (Pacific) $;-\mathrm{B}=$ from the Baltic Sea $;-\mathrm{N}=$ from the North Sea. Data are presented as median \pm median absolute deviation; different letters indicate significant differences $(\alpha=0.05)$

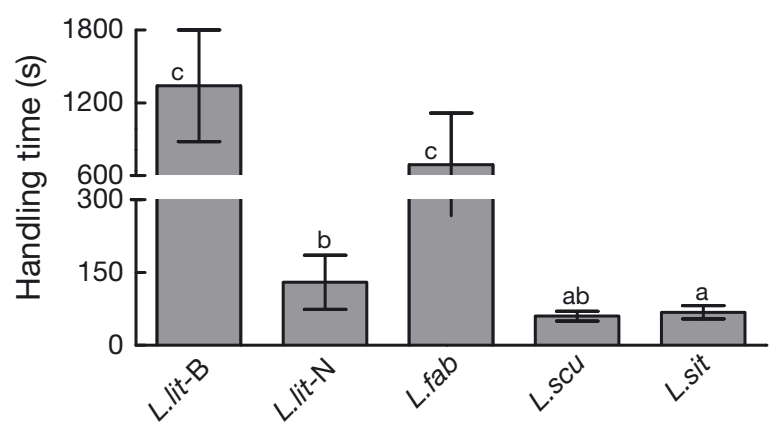

Fig. 4. Handling time of large periwinkles by Baltic crabs. Data are presented as median \pm median absolute deviation; different letters indicate significant differences $(\alpha=0.05)$

fered only slightly (Fig. 5A). Pacific periwinkles, both L. scutulata (Fig. 5B) and L. sitkana (Fig. 5C), were broken significantly faster by Baltic and Pacific crabs than by North Sea crabs.

Correspondingly, Baltic and North Sea crabs were similarly successful in preying upon Littorina littorea from the Baltic, but showed clear differences when preying upon L. littorea from the North Sea (Fig. 6A). With Pacific periwinkles, both Baltic and Pacific crabs were highly successful, whereas North Sea crabs successfully preyed upon L. scutulata (Fig. 6B) and L. sitkana (Fig. 6C) in only about $50 \%$ of all attempts.

\section{DISCUSSION}

\section{Crab morphometry}

Carcinus maenas in their native Europe differ from C. maenas in an invaded region (Pacific Canada) based on morphological characteristics: 


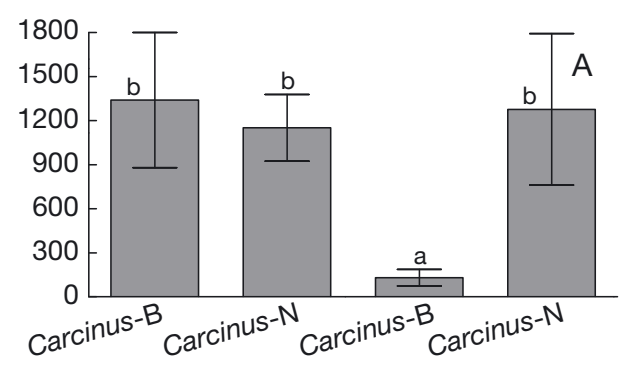

L. littorea-B $\quad$ L. littorea- $N$

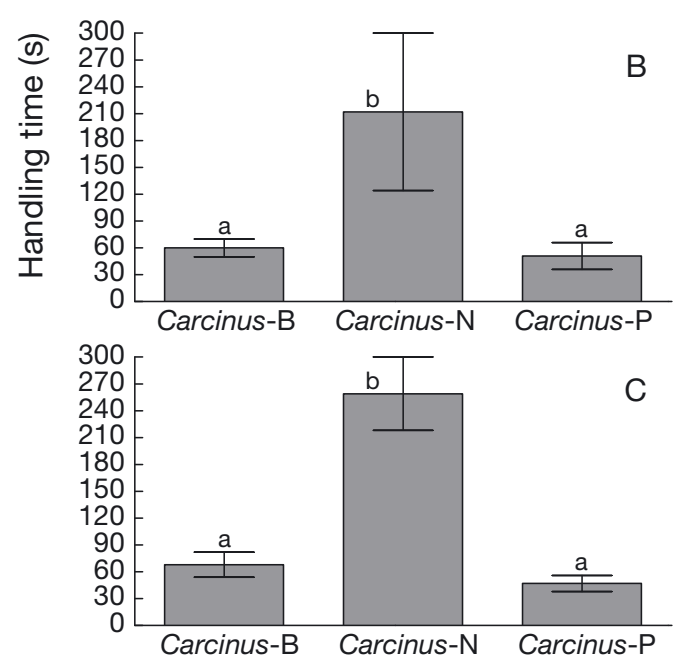

Fig. 5. Handling time of large periwinkles Littorina littorea (A), L. scutulata (B), and L. sitkana (C) by crabs of different origin $;-B$, from the Baltic Sea, $-N$, from the North Sea, $-P$, from the Pacific. Data are presented as median \pm median absolute deviation; different letters indicate significant differences $(\alpha=0.05)$

Pacific crabs in this study were significantly larger and had relatively larger claws compared to conspecifics in Europe. Based on the present data, we cannot unambiguously conclude whether this is a plastic response to environmental conditions, be it abiotic or biotic, or a result of the genetic background of the respective populations. On northwestern American Pacific coasts, green crabs experience close-to-ideal growing conditions and, hence, higher molting frequency and growth rates than in their native habitat (Behrens Yamada et al. 2005). Behrens Yamada \& Boulding (1998) demonstrated that crabs with greater propodal height (a proxy for mass of the closer muscle) crush snail shells more quickly than crabs with weaker claws. For crabs of similar size, claws of $C$. maenas were larger than of the native Pacific Cancer magister. Thus, the invasive C. maenas might be able to prey on hardshelled prey that reached a size refugium from predation by the native Pacific C. magister. According
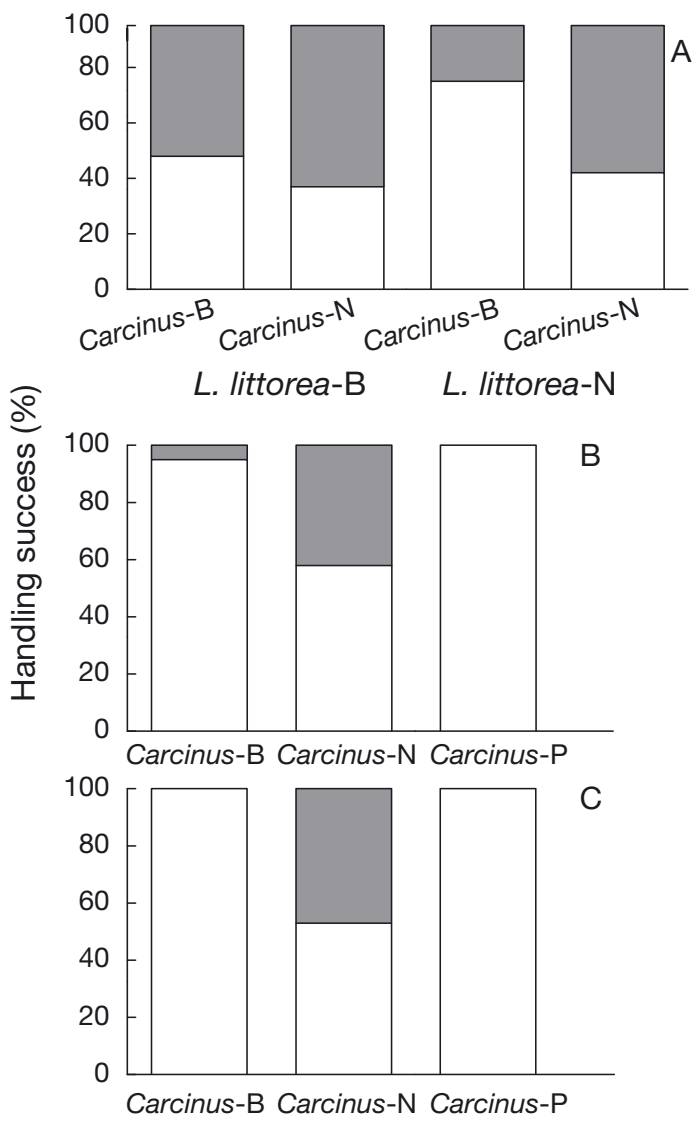

Fig. 6. Handling success on large periwinkles Littorina littorea (A), L. scutulata (B), and L. sitkana (C) by crabs of different origin; -B, from the Baltic Sea, $-N$, from the North Sea, -P, from the Pacific; white bars, successful; grey bars, unsuccessful

to Palmer et al. (1999), however, large claws exhibit lower relative biting forces than small claws of the same crab species, and even large Pacific Littorina spp. were soft-shelled enough to even be crushed by half of the North Sea crabs tested (see below). Hence, one might hypothesize that relatively larger claws are adaptive for invasive C. maenas in a context other than preying on periwinkles. Along the Pacific coast, green crabs are most abundant on mudflats, whereas both L. sitkana and L. scutulata live on hard substrata, potentially rendering them a minor prey for $C$. maenas. Thus, alternative hardshelled prey organisms along the North American Pacific coast might require thick-cuticled claws with high break resistance, as is probably the case for the larger claws in Pacific C. maenas (cf. Palmer et al. 1999). We did not measure crushing forces generated by the claws of the different crabs, but expect larger claws to be able to crush stronger prey shells (cf. Behrens Yamada \& Boulding 1998). 
The European populations from the Baltic and the North Sea were more similar to each other with respect to claw morphometry, suggesting either a closer genetic similarity (cf. Darling et al. 2008) or similar environmental conditions. The Baltic Sea and the North Sea significantly differ from each other in various abiotic characteristics (e.g. salinity, tides, habitat structure). In contrast, salinity and tidal conditions in the North Sea and the Canadian Pacific resemble each other more closely. Hence, we hypothesize that the biotic environment would at least partly modify body size and claw morphometry of green crabs, suggesting phenotypic plasticity or high adaptive potential, either of which would facilitate successful invasion of novel environments.

\section{Handling periwinkles}

Green crabs can handle some novel prey organisms as well as, or even better than, prey items they have prior experience with. The European periwinkles in this study are common across the native range of Carcinus maenas in coastal Central and North European waters. Thus, we expected European crabs to be well adapted to handling European periwinkles. Along with Littorina littorea and L. sitkana, which inhabit contrasting regions but are similar in shell shape, we chose the high-spired L. scutulata and the globose L. fabalis to disentangle geographical from morphological prey characteristics. We could, however, only partially separate the geographical origin and shell strength, since-except for North Sea L. littorea - European periwinkles had significantly stronger shells than Pacific periwinkles. Reasons for this finding remain obscure, since, whereas salinity in the Baltic Sea is markedly lower than at any other site studied herein, temperature conditions at the Baltic, North Sea, and Pacific sites strongly resemble each other.

Both shell morphometry and shell strength of periwinkles significantly correlated with prey-handling time by Baltic crabs. Handling times did not differ among prey species for North Sea and Pacific crabs. The bigger Pacific crabs with larger claws may be strong enough to successfully prey upon even wellprotected periwinkles (see above). However, we were unable to test Pacific crabs with the periwinkles species that took Baltic crabs the longest to crush, i.e. Baltic L. littorea and L. fabalis. Along the same line, small and medium-sized periwinkles were crushed irrespective of the species. By contrast, our present data suggest that North Sea crabs are too weak or inexperienced to frequently crush periwinkles successfully. Based on claw morphometry, we would expect Baltic and North Sea crabs to exert similar crushing forces, but we cannot provide data in this regard, since we did not determine claw force.

Alternative to crushing shells, crabs may either peel open the aperture to gain access to the flesh or winkle the flesh out of the intact shell (cf. Edgell \& Rochette 2009). We did not find any observational evidence that North Sea crabs were able to winkle the snail flesh out of shells that they could not crush, although C. maenas on North American Pacific coasts have been observed to do so when preying on Littorina sitkana (Hauck 2000) or L. obtusata (Edgell \& Rochette 2009). Had we fed North Sea crabs with Littorina spp. for an extended time interval, we might have been able to distinguish whether it is experience (plastic behavior) or local adaptation that renders a green crab capable of crushing snail shells or implementing alternative snail-feeding tactics.

We expected shell shape, e.g. high-spired versus globose, to influence handling by crabs. Our finding that Littorina scutulata and L. sitkana, differing in shell shape but not strength, took crabs the same time to handle, suggests that $C$. maenas is capable of successfully handling various shell shapes, although differences in shell shape have often been explained as adaptive to predators (Reid 1996, Edgell \& Rochette 2008). With large periwinkles, however, North Sea crabs were significantly less successful than were Baltic or Pacific crabs, suggesting that the former lack experience in handling periwinkles as potential prey (see above). Green crabs are known to be selective with regard to prey species (Elner \& Raffaelli 1980, Jensen \& Jensen 1985, Rangeley \& Thomas 1987) and prey size (Elner \& Hughes 1978, Hughes \& Elner 1979, Sanchez-Salazar et al. 1987, Juanes 1992, Enderlein et al. 2003). Geographic differences in diet may be due to prey availability and geographic differences in prey preference (for review, see Cohen et al. 1995). Thus Carcinus maenas may reject preying on Mytilus edutis even when they are abundant (Perkins 1967), and predation pressure on mussels may be low in the Baltic (Kautsky et al. 1990). Along the same line, there is indirect evidence that periwinkles do not necessarily contribute to the normal diet of green crabs in every population: $C$. maenas excluded Mytilus (cf. Enderlein \& Wahl 2004) but not Littorina from experimental field sites (Janke 1990), and crab predation on mussels is an important ecological and economic factor along North Sea coasts (Kamermans et al. 2009). Considering the possible lack of Littorina in the diet of C. mae- 
nas from the North Sea that may explain the inability to efficiently prey upon North Sea periwinkles, we conclude that (1) either the North Sea population did not play a role in the invasion of Pacific coasts (cf. Darling et al. 2008), or (2) green crabs are able to acclimate or adapt to novel food sources.

\section{CONCLUSIONS}

In terms of both handling time and handling success, Baltic Carcinus maenas did as well with Pacific periwinkles as did Pacific C. maenas, and even handled Pacific periwinkles much faster than hardershelled Europeans. Based on this, we conclude that C. maenas feeding behaviour is plastic, allowing for individual acclimation with novel prey organisms. Currently, C. maenas seems too rare on recently invaded North American Pacific coasts to exert any measurable effect on the community or ecosystem level. If, however, successful recruitment or northward currents increase green crab abundance on these shores (Behrens Yamada \& Kosro 2009), these invaders could potentially affect native benthic communities or shellfish culture.

Acknowledgements. We are grateful to E. Boulding, B. Cameron, J. Shurin, and Beth and Brad Anholt, Bamfield Marine Sciences Centre, for their support and help during office, lab and field work. We thank K. Johannesson, Tjärnö, for sending L. fabalis. H. Brendelberger, Kiel, provided office and lab space to G.S. An anonymous reviewer provided valuable insight into the biology of invasive green crabs on North American Pacific coasts.

\section{LITERATURE CITED}

Baldridge AK, Smith LD (2008) Temperature constraints on phenotypic plasticity explain biogeographic patterns in predator trophic morphology. Mar Ecol Prog Ser 365: 25-35

Behrens Yamada S, Boulding EG (1998) Claw morphology, prey size selection and foraging efficiency in generalist and specialist shell-breaking crabs. J Exp Mar Biol Ecol 220:191-211

Behrens Yamada S, Gillespie GE (2008) Will the European green crab (Carcinus maenas) persist in the Pacific Northwest? ICES J Mar Sci 65:725-729

> Behrens Yamada S, Kosro PM (2009) Linking ocean conditions to year class strength of the invasive European green crab, Carcinus maenas. Biol Invasions 12: 1791-1804

> Behrens Yamada S, Navarrete SA, Needham C (1998) Predation induced changes in behavior and growth rate in three populations of the intertidal snail, Littorina sitkana (Philippi). J Exp Mar Biol Ecol 220:213-226

Behrens Yamada S, Dumbauld BR, Kalin A, Hunt CE, FiglarBarnes R, Randall A (2005) Growth and persistence of a recent invader Carcinus maenas in estuaries of the northeastern Pacific. Biol Invasions 7:309-321

Behrens Yamada S, Davidson TM, Fisher S (2010) Claw morphology and feeding rates of introduced European green crabs (Carcinus maenas L, 1758) and native dungeness crabs (Cancer magister Dana, 1852). J Shellfish Res 29: 471-477

> Boulding EG, Harper FM (1998) Increasing precision in randomised field experiments: barnacle microtopography as a predictor of Littorina abundance. Hydrobiologia 378: 105-114

Breen E, Metaxas A (2003) A comparison of predation rates by non-indigenous and indigenous crabs (juvenile Carcinus maenas, juvenile Cancer irroratus, and adult Dyspanopeus sayi) in laboratory and field experiments. Estuaries Coasts 31:728-737

Cohen AN, Carlton JT, Fountain MC (1995) Introduction, dispersal and potential impacts of the green crab Carcinus maenas in San Francisco Bay, California. Mar Biol 122:225-237

Crothers JH (1968) The biology of the shore crab Carcinus maenas (L.) 2. The life of the adult crab. Field Stud 2:579-614

Darling JA, Bagley MJ, Roman J, Tepolt CK, Geller JB (2008) Genetic patterns across multiple introductions of the globally invasive crab genus Carcinus. Mol Ecol 17: 4992-5007

$>$ Dalziel B, Boulding EG (2005) Water-borne cues from a shell-crushing predator induce a more massive shell in experimental populations of an intertidal snail. J Exp Mar Biol Ecol 317:25-35

$>$ Edgell TC, Rochette R (2008) Differential snail predation by an exotic crab and the geography of shell-claw covariance in the northwest Atlantic. Evolution 62: 1216-1228

Edgell TC, Rochette R (2009) Prey-induced changes to a predator's behaviour and morphology: Implications for shell-claw covariance in the northwest Atlantic. J Exp Mar Biol Ecol 382:1-7

> Elner RW, Hughes RN (1978) Energy maximization in the diet of the shore crab Carcinus maenas. J Anim Ecol 47: 103-116

> Elner RW, Raffaelli DH (1980) Interactions between two marine snails, Littorina rudis Maton and Littorina nigrolineata Gray, a predator, Carcinus maenas (L.) and a parasite, Microphallus similis Jagerskiold. J Exp Mar Biol Ecol 43:151-160

Elton CS (1958) The ecology of invasions by animals and plants. Methuen, London

> Enderlein P, Wahl M (2004) Dominance of blue mussels versus consumermediated enhancement of benthic diversity. J Sea Res 51:145-155

Enderlein P, Moorthi S, Roehrscheid H, Wahl M (2003) Optimal foraging versus shared doom effects: interactive influence of mussel size and epibiosis on predator preference. J Exp Mar Biol Ecol 292:231-242

Hauck LL (2000) Use of tethered prey for estimating the impact of the invasive European green crab. BSc thesis. Oregon State University, Corvallis, OR

$>$ Hughes RN, Elner RW (1979) Tactics of a predator, Carcinus maenas, and morphological responses of the prey, Nucella lapillus. J Anim Ecol 48:65-78

> Hunt CE, Behrens Yamada S (2003) Biotic resistance experienced by an invasive crustacean in a temperate estuary. Biol Invasions 5:33-43 
Janke K (1990) Biological interactions and their role in community structure in the rocky intertidal of Helgoland (German bight, North Sea). Helgol Meersunters 44: 219-263

> Jensen KT, Jensen JN (1985) The importance of some epibenthic predators on the density of juvenile benthic microfauna in the Danish Wadden Sea. J Exp Mar Biol Ecol 89:157-174

Johannesson K (2003) Evolution in Littorina: ecology matters. J Sea Res 49:107-117

Juanes F (1992) Why do decapod crustaceans prefer smallsized molluscan prey? Mar Ecol Prog Ser 87:239-249

Kamermans P, Blankendaal M, Perdon J (2009) Predation of shore crabs (Carcinus maenas (L.)) and starfish (Asterias rubens L.) on blue mussel (Mytilus edulis L.) seed from wild sources and spat collectors. Aquaculture 290: 256-262

Kautsky N, Johannesson K, Tedengren M (1990) Genotypic and phenotypic differences between Baltic and North Sea populations of Mytilus edulis evaluated through reciprocal transplantations. I. Growth and morphology. Mar Ecol Prog Ser 59:203-210

Keppel E, Scrosati R (2004) Chemically mediated avoidance of Hemigrapsus nudus (Crustacea) by Littorina scutulata (Gastropoda): effects of species coexistence and variable cues. Anim Behav 68:915-920

Kishida O, Trussell GC, Mougi A, Nishimura K (2010) Evolutionary ecology of inducible morphological plasticity in predator-prey interaction: toward the practical links with population ecology. Popul Ecol 52:37-46

Lewis TL, Mews M, Jelinski DE, Zimmer M (2007) Detrital subsidy to the supratidal zone provides feeding habitat

Editorial responsibility: Roger Hughes,

Bangor, UK for intertidal crabs. Estuaries Coasts 30:451-458

Lima SL, Dill LM (1990) Behavioural decisions made under the risk of predation: a review and prospectus. Can J Zool 68:619-640

Lockwood JL, Hoopes MF, Marchetti MP (2007) Invasion Ecology. Blackwell, Malden, MA, USA

Naylor E (1960) Locomotory rhythms in Carcinus maenas (L.) from non-tidal conditions. J Exp Biol 37:481-488

Palmer RA, Tayler GM, Barton A (1999) Cuticle strength and the size-dependence of safety factors in Cancer crab claws. Biol Bull 196:281-294

Perkins EJ (1967) Some aspects of the biology of Carcinus maenas (L.). Trans Dumfriesshire Galloway Natl Hist Antiquarian Soc Series 3 44:47-56

> Rangeley RW, Thomas MLH (1987) Predatory behaviour of juvenile shore crab Carcinus maenas (L.). J Exp Mar Biol Ecol 108:191-197

Reid DG (1996) Systematics and evolution of Littorina. Ray Society, London

> Rochette R, Dill LM (2000) Mortality, behaviour and the effects of predators on the intertidal distribution of littorinid gastropods. J Exp Mar Biol Ecol 253:165-191

Sanchez-Salazar ME, Griffiths CL, Seed R (1987) The effect of size and temperature on the predation of cockles Cerastoderma edule (L.) by the shore crab Carcinus maenas (L.). J Exp Mar Biol Ecol 111:181-193

> Smith LD, Palmer A (1994) Effects of manipulated diet on size and performance of brachyuran crab claws. Science 264:710-712

> Vermeij GJ (1982) Phenotypic evolution in a poorly dispersing snail after arrival of a predator. Nature 299:349-350

Submitted: August 23, 2012; Accepted: January 22, 2013 Proofs received from author(s): May 4, 2013 